\title{
DAMPAK PERKEMBANGAN CITY HOTEL TERHADAP USAHA HOTEL MELATI DI KOTA DENPASAR
}

\author{
Ketut Ngurah Trisni Sakawati \\ E-mail: trisnisaka@gmail.com
}

\begin{abstract}
The tourism sector of Bali has developed rapidly in the last ten years, especially when it is seen from the trend of the numbers of domestic and foreign tourist arrivals. This trend is accompanied with the increasing number of accommodation facilities. Denpasar is a region which shows the rapid growth of accommodation facilities, such as the presence of a number of hotels in the city area which is often referred to as a city hotel. This study examines the factors that cause the growth of city hotels, the impacts of the city hotel growths on the budget hotel businesses, the competition and business strategies of inter-city hotels as well as their influences on business strategies of budget hotels in Denpasar City. The theories applied in the study were the theory of supply and demand, the impact theory and the theory of tourism policy. Data were collected through observation and interviews with relevant tourism stakeholders. The findings show the rapid developments of the city hotels have given negatif and positive impacts on the businesses of the budget hotels in Denpasar. To prevent excessive development of the city hotel, it is recommended to Denpasar government to develop a needs assessment of hotel rooms and some policies such as standard setting policies of room rates or equitable policy of the hotel developments.
\end{abstract}

Keywords: Denpasar tourism, city hotel, the impacts of development, budget hotel.

\section{Pendahuluan}

Pariwisata Bali berkembang pesat dalam sepuluh tahun terakhir, terutama jika dilihat dari tren angka kunjungan wisatawan domestik dan asing. Tren kunjungan wisatawan juga diikuti dengan bertambahnya jumlah sarana akomodasi. Denpasar merupakan salah satu wilayah di Provinsi Bali menunjukkan pertumbuhan sarana akomodasi yang pesat. Perkembangan model sarana akomodasi di Kota Denpasar saat ini dikenal dengan istilah city hotel.

Menurut Ismayanti dalam buku Pengantar Pariwisata (2010:139) bahwa 
tipe hotel dapat dibagi menjadi beberapa aspek salah satunya berdasarkan lokasi. Berdasarkan lokasi, hotel dapat dibedakan menjadi beberapa istilah sebagai contoh, city hotel adalah hotel yang berlokasi diperkotaan. Pesatnya perkembangan city hotel di Kota Denpasar sangat dirasakan dampaknya oleh pengusaha hotel melati dan antara city hotel.

Data Statistik Kota Denpasar Tahun 2014 menunjukkan terjadinya peningkatan jumlah hotel bintang tahun 2012 dari 25 menjadi 27 pada tahun 2013. Sedangkan, jumlah hotel non-bintang dari 236 pada tahun 2012 menjadi 253 di tahun 2013. Jumlah kamar hotel bintang pada tahun 2013 sebanyak 3.705 dan hotel non-bintang sejumlah 5.834 kamar. Tingkat hunian kamar pada hotel bintang tahun 2013 sekitar 50,62 persen, terjadi penurunan dibandingkan pada tahun 2012 tingkat hunian kamar mencapai 58,12 persen. Tingkat hunian kamar hotel non-bintang tahun 2012 sebanyak 30,50 persen menurun menjadi 26,31 persen pada tahun 2013. Rata-rata lama menginap di hotel bintang terjadi peningkatan dari 2,90 hari di tahun 2012 menjadi 3,24 hari di tahun 2013 dengan rata-rata lama menginap di hotel non-bintang juga mengalami peningkatan dari 2,87 hari di tahun 2012 menjadi 3,12 hari di tahun 2013.

Fenomena tersebut menunjukkan telah terjadi penurunan pada tingkat hunian kamar baik di hotel bintang maupun hotel non-bintang di bawah 50 persen. Penurunan tingkat hunian hotel dapat disebabkan oleh beberapa hal seperti menurunnya jumlah wisatawan yang menginap di Kota Denpasar sebesar 13,62 persen pada tahun 2013 mencapai 364.322 orang dibandingkan pada tahun 2012 (Data Statistik Daerah Kota Denpasar Tahun 2014).

Perkembangan hotel di Denpasar tidak saja memberikan tambahan fasilitas akomodasi bagi Kota Denpasar, namun pembangunan hotel yang lokasinya berada di pusat kota dan dikenal dengan istilah city hotel sering menimbulkan permasalahan. Beberapa city hotel yang dikelola oleh manajemen profesional berjaringan Nasional ataupun Internasional menawarkan fasilitas sekelas hotel bintang dengan harga sewa kamar sekelas hotel melati. Hal ini menimbulkan persaingan yang tidak sehat antara hotel melati dengan city hotel. Pesatnya pembangunan hotel baru di tengah kota sudah barang tentu memberikan kontribusi kelebihan jumlah kamar yang terjadi dan memberikan dampak secara tidak langsung kepada tingkat hunian hotel, pendapatan hotel dan persaingan harga sewa kamar.

Timbulnya persaingan harga sewa kamar berimplikasi terhadap semakin murahnya penawaran paket wisata yang ditawarkan oleh biro perjalanan wisata, apalagi saat ini biro perjalanan wisata dengan mudah menawarkan produknya melalui internet. Dengan kondisi semacam itu, semakin menguatkan Bali sebagai destinasi murah sehingga wisatawan yang datang ke Bali bukanlah seperti yang diharapkan banyak orang yaitu wisatawan yang berkualitas namun masih mengarah kepada wisatawan massal (mass 
tourism).

Sehubungan dengan itu, perlu dilakukan penelitian tentang perkembangan city hotel yang memberikan dampak terhadap usaha hotel melati di Kota Denpasar agar pengusaha hotel melati dapat berbenah diri dalam menghadapi persaingan yang akan terjadi. Dengan adanya dampak tersebut, muncul beberapa pertanyaan mengenai apakah dengan kehadiran city hotel akan mendesak keberadaan hotel melati atau sebaliknya. Pertanyaan lainnya adalah apakah kehadiran city hotel justru akan berebut pasar dengan hotel sekelasnya ataukah munculnya city hotel tidak berpengaruh terhadap usaha hotel melati karena masing-masing telah memiliki pasar tersediri. Dalam penelitian ini juga akan dibahas mengenai pentingnya sebuah kebijakan pemerintah dalam mengatur bisnis perhotelan di Kota Denpasar.

Artikel ini hendak menjawab tiga persoalan yaitu, (a) apakah faktorfaktor yang menyebabkan berkembanganya city hotel di Kota Denpasar?; (b) apakah dampak berkembangnya city hotel terhadap usaha hotel melati di Kota Denpasar?; (c) bagaimanakah persaingan dan strategi bisnis antar city hotel serta pengaruhnya terhadap strategi bisnis hotel melati di Kota Denpasar?

\section{Teori dan Metode Penelitian}

Dalam artikel ini digunakan tiga teori sebagai tuntunan dalam memecahkan permasalahan, selain itu juga digunakan sebagai kerangka acuan untuk mengarahkan penelitian. Landasan teori yang digunakan adalah teori penawaran dan permintaan, teori dampak pariwisata, dan teori kebijakan kepariwisataan.

\subsection{Teori Penawaran dan Permintaan}

Teori Penawaran dan Permintaan, menurut Sukirno (1985:51), membahas mengenai interaksi antara penjual dan pembeli dalam menentukan harga suatu barang dan jumlah barang yang akan ditawarkan. Pengertian teori penawaran adalah semakin turun harga barang, penawaran akan semakin sedikit sedangkan hukum permintaan adalah semakin rendah harga barang, permintaan akan barang tersebut semakin tinggi.

Usaha akomodasi merupakan bagian dari komponen produk (supply side) suatu destinasi dalam rangka memenuhi kebutuhan komponen pasar (demand side). Pembangunan sarana akomodasi di Kota Denpasar diharapkan selaras dengan kunjungan wisatawan sehingga dapat meningkatkan tingkat hunian hotel dan akan lebih bagus bila diikuti dengan lama tinggal serta peningkatan pengeluaran wisatawan. Teori permintaan dan penawaran dalam artikel ini digunakan untuk menemukan faktor-faktor penyebab berkembangnya city hotel di Kota Denpasar dan persaingan antar-city hotel serta strategi bisnis yang digunakan dalam menawarkan hotelnya. Ada dua faktor yang akan 
digunakan yakni faktor internal dan eksternal.

Faktor internal terdiri dari harga sewa kamar, lokasi hotel, fasilitas yang ditawarkan, tingkat hunian kamar, lama tinggal tamu, dan pengelolaan hotel. Sedangkan faktor eksternal yang digunakan adalah dengan mencermati adanya tren wisatawan dalam pemilihan hotel saat berlibur, mudahnya proses perizinan hotel dan peluang untuk membangun hotel di Kota Denpasar.

\subsection{Teori Dampak Pariwisata}

Pertumbuhan industri pariwisata telah menjadi kontributor utama peningkatan aktivitas ekonomi di seluruh dunia, namun dampak yang muncul akibat pertumbuhan tersebut belum banyak dipahami (Kreag, 2010). Dampak pariwisata sering digunakan sebagai suatu kerangka pikir oleh para sarjana untuk membahas tentang dampak pariwisata di berbagai belahan dunia seperti Glen Kreag dalam bukunya The Impact of Tourism (2010) dan Peter Mason dalam bukunya Tourism Impacts, Planning and Management (2003).

Erik Cohen (dalam Pitana, 2005:109) menyebutkan dampak pariwisata terhadap kondisi sosial ekonomi masyarakat lokal dapat dikategorikan menjadi delapan kelompok besar yaitu: dampak terhadap penerimaan devisa, pendapatan masyarakat, kesempatan kerja, harga-harga, distribusi manfaat/ keuntungan, kepemilikan dan kontrol, pembangunan pada umumnya serta pendapatan pemerintah.

Pesatnya pembangunan sarana akomodasi pariwisata di Kota Denpasar dengan model city hotel juga telah menimbulkan dampak baik positif maupun negatif dan memberikan dampak sosial ekonomi, sosial budaya dan lingkungan terhadap seluruh komponen yakni pengusaha, masyarakat dan Pemerintah.

Mengidentifikasi dampak akibat perkembangan city hotel di Kota Denpasar terhadap usaha hotel melati dan city hotel itu sendiri merupakan langkah yang sangat penting agar perkembangan city hotel dapat dikendalikan dan hotel melati tetap mendapatkan bagian dari pembangunan pariwisata di Kota Denpasar. Faktor dampak yang diteliti adalah harga sewa kamar, jumlah tamu yang menginap, tingkat hunian kamar perbulan, pendapatan hotel, lama tinggal dan jenis tamu yang menginap. Dari Faktor tersebut dapat diidentifikasi dampak terhadap hotel melati akibat perkembangan city hotel di Kota Denpasar. Hasil identifikasi dampak ini akan digunakan sebagai bahan masukan dalam penyusunan kebijakan dalam rangka mengendalikan perkembangan city hotel di Kota Denpasar. Maksud dari penyusunan kebijakan adalah untuk memecahkan masalah yang terjadi akibat perkembangan city hotel yang menimbulkan persaingan tidak sehat antar pengusaha hotel di Kota Denpasar. 


\subsection{Teori Kebijakan Kepariwisataan}

Dalam arti sederhana, kebijakan adalah suatu tindakan yang mengarah pada tujuan tertentu yang dilakukan oleh seorang aktor atau sejumlah aktor berkenaan dengan suatu masalah atau persoalan tertentu. Kebijakan kepariwisataan yang dikemukakan oleh ahli-ahli pariwisata, Goeldner dan Ritchie (2006) mendefinisikan kebijakan pariwisata sebagai regulasi, aturan, pedoman, arah, dan sasaran pembangunan ataupun promosi serta strategi yang memberikan kerangka dalam pengambilan keputusan individu maupun kolektif yang secara langsung mempengaruhi pengembangan pariwisata dalam jangka panjang dan sekaligus kegiatan sehari-hari yang berlangsung di suatu destinasi. ${ }^{1}$

Isu yang berkembang saat ini di Kota Denpasar adalah maraknya pembangunan city hotel di kota ini yang menimbulkan kekhawatiran di berbagai kalangan baik masyarakat maupun pengusaha hotel melati. Teori kebijakan yang digunakan dalam artikel ini difokuskan kepada kebijakan kepariwisataan terhadap penataan sarana akomodasi di Kota Denpasar dengan isu berkembangnya city hotel di Kota Denpasar. Teori kebijakan ini akan digunakan untuk menganalisis dampak berkembangnya city hotel terhadap usaha hotel melati di Kota Denpasar dengan faktor harga sewa kamar, tingkat hunian hotel, jumlah tamu menginap, pendapatan hotel, lama tinggal tamu dan jenis tamu. Dengan faktor tersebut dapat diketahui apakah dampak yang terjadi dapat sebagai pertimbangan dalam penyusunan kebijakan publik dalam pengaturan dan pengendalian pembangunan city hotel di Kota Denpasar.

\subsection{Metode Penelitian}

Penelitian inimenggunakan pendekatan penelitian kualitatif untuk melihat dampak akibat berkembangnya city hotel terhadap usaha hotel melati di Kota Denpasar dengan melakukan melakukan pengamatan, wawancara dan dokumentasi. Dalam penelitian ini yang dimaksud dengan city hotel adalah hotel hotel kelas bintang dengan lokasi strategis di pusat kota. Penelitian dilakukan terhadap 6 city hotel kelas bintang dan 13 hotel melati di empat kecamatan di Kota Denpasar pada saat masa liburan yang bertepatan dengan libur hari raya Imlek pada bulan Februari 2015 ataupun sekitar bulan Maret 2015 yang bertepatan dengan tengah semester anak-anak sekolah.

Jenis data yang dicari adalah data kualitatif dan kuantitatif. Yang dimaksud dengan data kualitatif adalah data mengenai faktor-faktor penyebab berkembangnya city hotel, dampak yang muncul akibat berkembangnya city hotel, persaingan dan strategi bisnis antar-city hotel serta pengaruhnya terhadap strategi bisnis hotel melati di Kota Denpasar. Sedangkan data kuantitatif dalam penelitian ini adalah data kepariwisataan seperti mengenai

http://tentangpariwisata. blogspot.com/2010/12/apa-itu-kebijakan kepariwisataan.html 
jumlah hotel bintang dan non-bintang di Kota Denpasar, jumlah kunjungan wisatawan dan data pendukung lainnya.

Dalam penelitian ini, data primer didapat dari hasil wawancara dan observasi terhadap pengusaha hotel melati, pengusaha city hotel, tamu dari kedua hotel, asosiasi perhotelan, asosiasi biro perjalanan wisata dan Pemerintah. Data sekunder adalah data yang diperoleh tidak secara langsung dari informan, tetapi dari pihak ketiga, yakni data-data yang berasal dari dokumen-dokumen yang ada di wilayah tersebut maupun di perpustakaan.

Peneliti melakukan wawancara dengan pihak-pihak terkait dengan menggunakan kuisioner yang berisi pedoman wawancara. Dalam penelitian ini penentuan sampel dilakukan dengan teknik purposive sampling yang mengambil sumber data dengan pertimbangan tertentu yang dianggap mengetahui tentang apa yang sedang diteliti.

Sehubungan dengan rancangan penelitian ini menggunakan metode penelitian kualitatif maka dalam menganalisis data digunakan secara deskriptif kualitatif. Selanjutnya penyajian hasil analisis data dilakukan secara formal dalam bentuk naratif, gambar, tabel ataupun grafik. Penyajian data dalam bentuk naratif untuk menyampaikan temuan faktor-faktor penyebab berkembangnya city hotel di Kota Denpasar dan menganalisis hasil wawancara yang didapat mengenai dampak perkembangan city hotel, persaingan dan strategi bisnis antar-city hotel serta pengaruhnya terhadap strategi bisnis hotel melati di Kota Dari hasil analisa tersebut disusun mengenai kondisi yang terjadi di lapangan akibat berkembangnya city hotel di Kota Denpasar (Foto 1).

\section{Perkembangan City Hotel di Denpasar}

Sebagai ibu kota Provinsi Bali, Denpasar mengalami perkembangan awal dalam berbagai sektor termasuk sector pariwisata. Di Denpasar-lah hotel pertama dibangun, yaitu Bali Hotel, didirkan oleh KPM Belanda tahun 1928. Walaupun sekarang perkembangan pariwisata Denpasar dilampaui oleh Kabupaten Badung ditandai dengan perkembangan kawasan Nusa Dua, Kuta dan sekitarnya, namun Denpasar tetap menjadi salah satu pusat perkembangan pariwisata Bali. Di Denpsar bertumbuhan banyak city hotel, sehingga hamper di setiap sudut kota sekarang ada hotel, sesuatu yang tidak ada sebelumnya, tahun 1990-an ke belakang.

Faktor-faktor penyebab berkembangnya city hotel di Kota Denpasar dianalisis menggunakan teori penawaran dan permintaan. Uraian dengan teori ini dikaitkan dengan faktor internal yang meliputi harga sewa kamar (room rate), fasilitas yang ditawarkan, lokasi hotel, tingkat hunian kamar hotel, lama tinggal wisatawan, dan pengelolaan hotel. Faktor ini dimasukkan sebagai faktor internal hotel karena berkaitan langsung dengan operasional hotel ke dalam. Selain faktor-faktor internal tersebut, ada juga faktor eksternal 


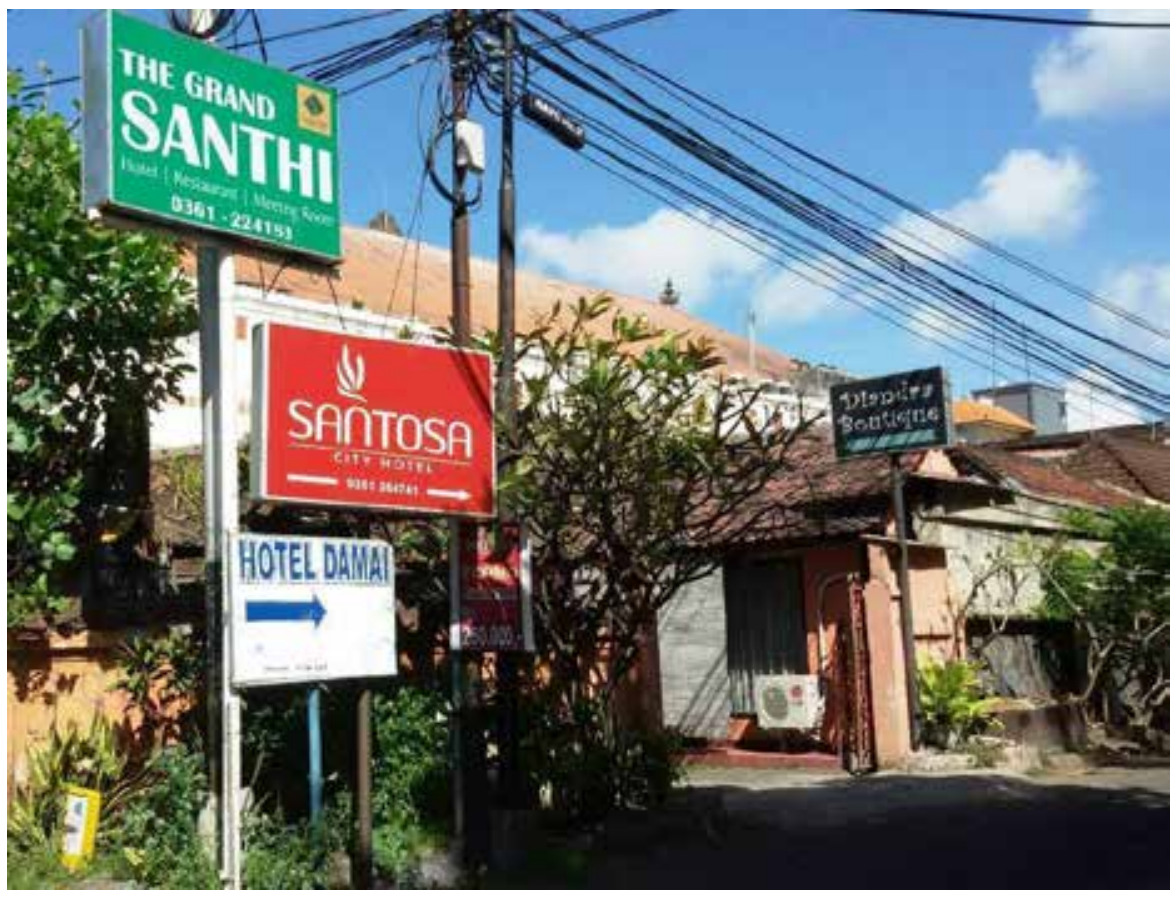

KETUT NGURAH TRISNI SAKAWATI

Foto 1. City hotel bertumbuhan di Denpasar seperti tampak dari papan-papannya di sudut Jaln Sudirman.

yang menjadi penyebab berkembangnya city hotel di Kota Denpasar seperti adanya tren wisatawan dalam pemilihan hotel saat berlibur, mudahnya proses perizinan hotel, dan peluang untuk membangun hotel di Kota Denpasar.

Materi untuk analisis diperoleh dari hasil wawancara dengan pengelola hotel baik city hotel maupun hotel melati, pejabat di Dinas Pariwisata Kota Denpasar, dan Badan Pelayanan Perizinan Satu Pintu dan Penanaman Modal Kota Denpasar serta beberapa tamu yang sedang menginap di hotel.

Secara umum, harga merupakan salah satu faktor yang dipakai sebagai pertimbangan bagi konsumen dalam memilih suatu produk. Harga memainkan peranan penting karena mampu merebut hati para konsumen dan calon konsumen dalam mengambil suatu keputusan (Budi, 2103:100).

Untuk mengetahui sejauh mana harga sewa kamar ini mempengaruhi faktor-faktor yang menyebabkan perkembangan city hotel, maka peneliti mewawancarai 35 orang tamu yang menginap di 16 hotel berbeda. Dari 35 orang tamu yang menginap di 16 hotel tersebut, 16 orang di antaranya menyatakan bahwa mereka memilih hotel karena harga. Dalam hukum permintaan, konsumen selalu tertarik dengan harga yang rendah sehingga permintaan akan barang yang ditawarkan semakin meningkat. Demikian pula halnya dengan harga sewa kamar hotel yang rendah sangat menarik bagi 
wisatawan sehingga mereka memilih harga yang sesuai dengan kemampuan finansial dan keinginan yang ingin dicapai. Berdasarkan fenomena di atas sebagian besar tamu memilih hotel karena faktor harga yang sesuai dengan fasilitas yang ada.

Selain harga sewa kamar, lokasi hotel juga menjadi salah satu faktor penting bagi tamu dalam menentukan pilihannya. Seperti yang telah disebutkan bahwa pengertian city hotel adalah hotel yang berlokasi di tengah kota dan dikunjungi oleh pebisnis, maka dari itu salah satu faktor dari faktor penyebab berkembangnya city hotel adalah lokasi. Makna sebuah lokasi strategis atau tidak berbeda dari satu tamu ke tamu lainnya yang biasanya sesuai dengan kepentingannya.

Teori permintaan dan penawaran yang ada dalam faktor ini adalah dimana tamu memilih hotel karena lokasi yang strategis untuk memudahkan mobilitasnya selama di Kota Denpasar, artinya semakin banyak tamu yang lebih mementingkan lokasi daripada harga atau fasilitas. Dari sisi penawaran, pemilik hotel melihat peluang tersebut sehingga dalam promosi yang dilakukan selalu menyebutkan lokasi yang strategis, dan aksesibilitas yang mudah dicapai sehingga memudahkan tamu untuk melakukan akitivitas selama di daerah tersebut.

Menurut Darminto dan Suryo dalam buku Analisis Laporan Keuangan Hotel (2005) persentase tingkat hunian kamar adalah angka berdasarkan perhitungan jumlah kamar yang dipakai selama periode tertentu dibagi dengan jumlah kamar yang tersedia selama periode yang sama dan dikalikan 100 persen. Secara umum kondisi tingkat hunian ganda tentu akan lebih menguntungkan hotel dibandingkan dengan tingkat hunian tunggal, di mana kamar hanya dihuni oleh satu orang saja, karena pemanfaatan fasilitas hotel akan lebih tinggi.

Hasil penelitian menunjukkan sebagian besar pengelola hotel menyatakan tingkat hunian hotel semakin hari semakin menurun. Hasil penelitian di beberapa hotel menunjukkan, hotel kelas melati mempunyai tingkat hunian yang tinggi pada musim liburan sekolah (Lihat Foto 2).

Lama tinggal tamu di suatu hotel adalah jangka waktu seorang tamu menginap di suatu hotel. Lama tinggal seorang tamu tergantung dari tujuan kunjungannya ke suatu destinasi. Bila tujuannya adalah untuk berkunjung ke daya tarik wisata yang ada di destinasi tersebut biasanya tamu menginap selama tiga hari atau dua malam.

Hasil penelitian menunjukkan sebagian besar pengelola hotel menyatakan lama tinggal tamu yang saat ini hanya sekitar 2-3 hari. Faktor harga, lokasi hotel, fasilitas hotel, pelayanan hotel dan promosi sangat mempengaruhi tingkat hunian hotel.

Saat ini di Kota Denpasar banyak dibangun city hotel baik yang dikelola oleh perseorangan ataupun manajemen hotel dengan jaringan kelas dunia 


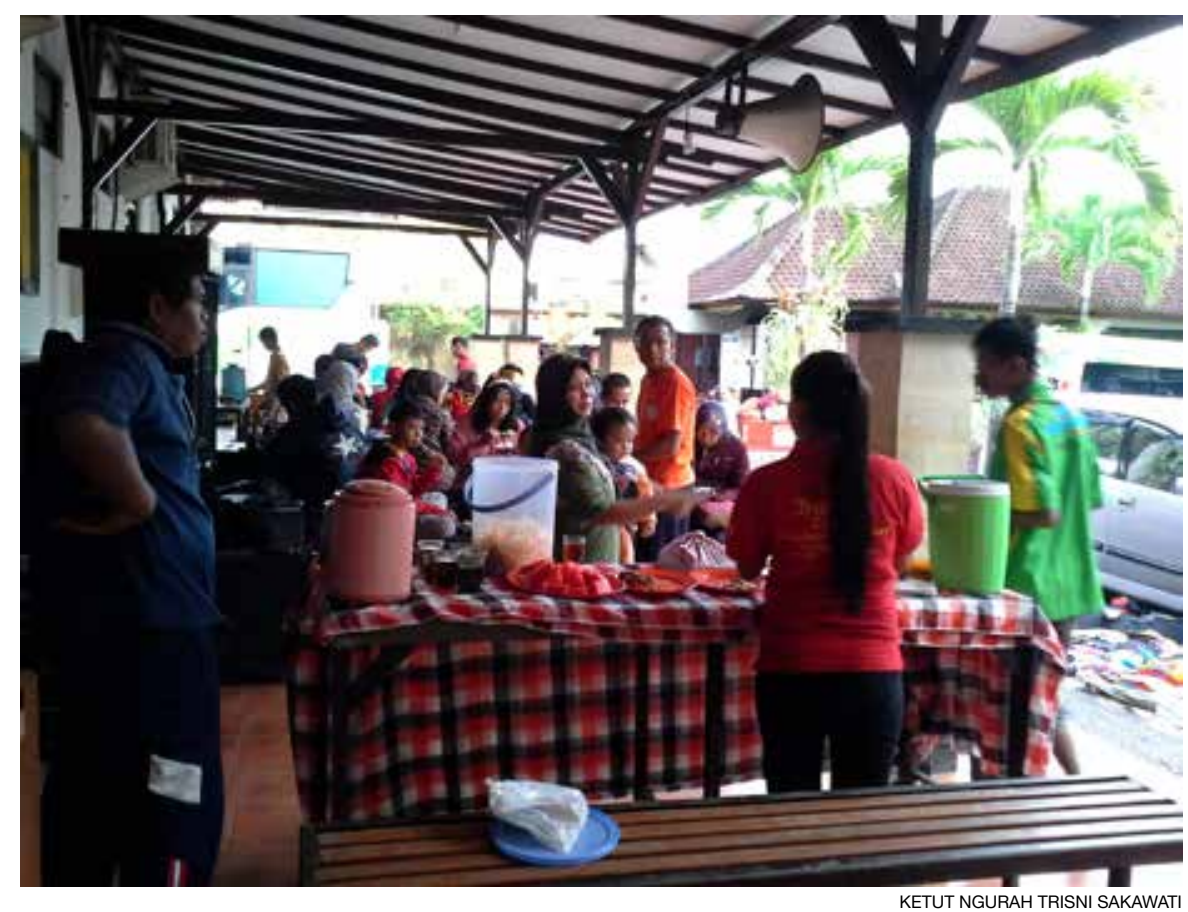

Foto 2. Wisaatwan domestik di sebuah hotel melati

seperti grup Accor, Aston, Tauzia ataupun Santika yang merupakan salah satu anggota Kompas Gramedia Group. Manajemen hotel jaringan internasional (international chain hotel) ini dengan cepat mewarnai bisnis hotel di Kota Denpasar yang berlokasi di tempat-tempat strategis sehingga secara kasat mata sangat menarik perhatian. Hal ini terjadi karena tren masyarakat yang menginginkan fasilitas hotel kelas bintang dengan harga kelas melati.

\subsection{Tren Wisatawan dalam Memilih Hotel}

Berkembangnya city hotel di Kota Denpasar telah memberikan kesempatan kepada tamu untuk memilih akomodasi selama berlibur. Para tamu biasanya memperkirakan tawaran mana yang akan memberikan nilai maksimal yang dibatasi oleh biaya pencarian, pengetahuan, mobilitas dan pendapatan (Budi, 2013). Bila dicermati dari hasil wawancara dengan tamu ditemukan 14 orang yang memilih hotel karena lokasi, 8 orang yang memilih hotel karena harga, fasilitas serta pelayanan yang diberikan. Sedangkan 13 orang lainnya memilih karena harga, harga dan lokasi, rekomendasi biro perjalanan wisata ataupun lokasi serta fasilitas.

\subsection{Kemudahan dalam Proses Perizinan}

Dalam rangka meningkatkan pelayanan publik yang cepat, murah, mudah, transparan, pasti dan terjangkau, serta mampu meningkatkan hak- 
hak masyarakat dalam pelayanan publik maka Pemerintah Kota Denpasar melalui Badan Pelayanan Perijinan Terpadu Satu Pintu dan Penanaman Modal (BPPTSP\&PM) berupaya membangun dan menciptakan mekanisme pelayanan sederhana.

Sebagaimana yang disampaikan oleh beberapa pengelola hotel yang diwawancarai bahwa tidak menemukan kendala dalam pengurusan izin. Hal ini disebabkan pengelola telah memiliki kelengkapan dokumen dan memenuhi persyaratan yang diperlukan.

\subsection{Adanya Peluang Pembangunan Hotel}

Tingginya minat investor dalam membangun hotel di Kota Denpasar karena adanya peluang seperti tercantum dalam dokumen Rencana Tata Ruang Wilayah (RTRW) Kota Denpasar. Pada Bagian Ketiga, Rencana Pengembangan Kawasan Budidaya, Paragraf 5 Kawasan Peruntukan Pariwisata, Pasal 47 ayat 3 disebutkan Rencana pengembangan akomodasi wisata di wilayah Kota melalui Pengembangan pada zona pariwisata dan pengembangan menyebar di luar zona Kawasan Pariwisata Sanur. Selanjutnya pada poin b diuraikan Pengembangan akomodasi menyebar merupakan akomodasai wisata atau hotel kota (city hotel) lokasinya dapat menyatu dengan zoning perdagangan dan jasa dan kawasan pemukiman tertentu. Dengan demikian pembangunan city hotel di Kota Denpasar masih dimungkinkan namun dengan memperhatikan pembagian peruntukan wilayah agar tidak terjadi pelanggaran pemanfaatan ruang dan bangunan.

\section{Dampak Berkembangnya City Hotel terhadap Hotel Melati}

Pesatnya pembangunan city hotel di Kota Denpasar telah memberikan dampak kepada pengusaha hotel melati. Dampak perkembangan city hotel terhadap usaha hotel melati dianalisis menggunakan teori dampak pariwisata dengan faktor (a) harga sewa kamar, (b) jumlah tamu yang menginap, (c) tingkat hunian kamar, (d) pendapatan hotel, (e) lama tinggal dan jenis tamu yang menginap.

Penelitian dilakukan dengan melakukan wawancara dengan pengelola hotel melati, pejabat di empat kecamatan di Kota Denpasar, pejabat Dinas Pariwisata Kota Denpasar, Badan Pelayanan Perizinan Terpadu Satu Pintu dan Penanaman Modal Kota Denpasar dan Bagian Hukum Setda. Kota Denpasar, Perwakilan Pengurus Asosiasi Perhotelan (PHRI) Kota Denpasar dan ASITA Bali. Hasil penelitian menunjukkan bahwa pesatnya perkembangan sarana akomodasi dengan model city hotel telah memberikan dampak negatif terhadap usaha hotel melati di Kota Denpasar, seperti yang diulas berikut ini (Foto 3).

Para pengelola hotel melati di Denpasar yang kebanyakan merupakan penduduk lokal dan mengelola hotel dengan manajemen keluarga sangat 


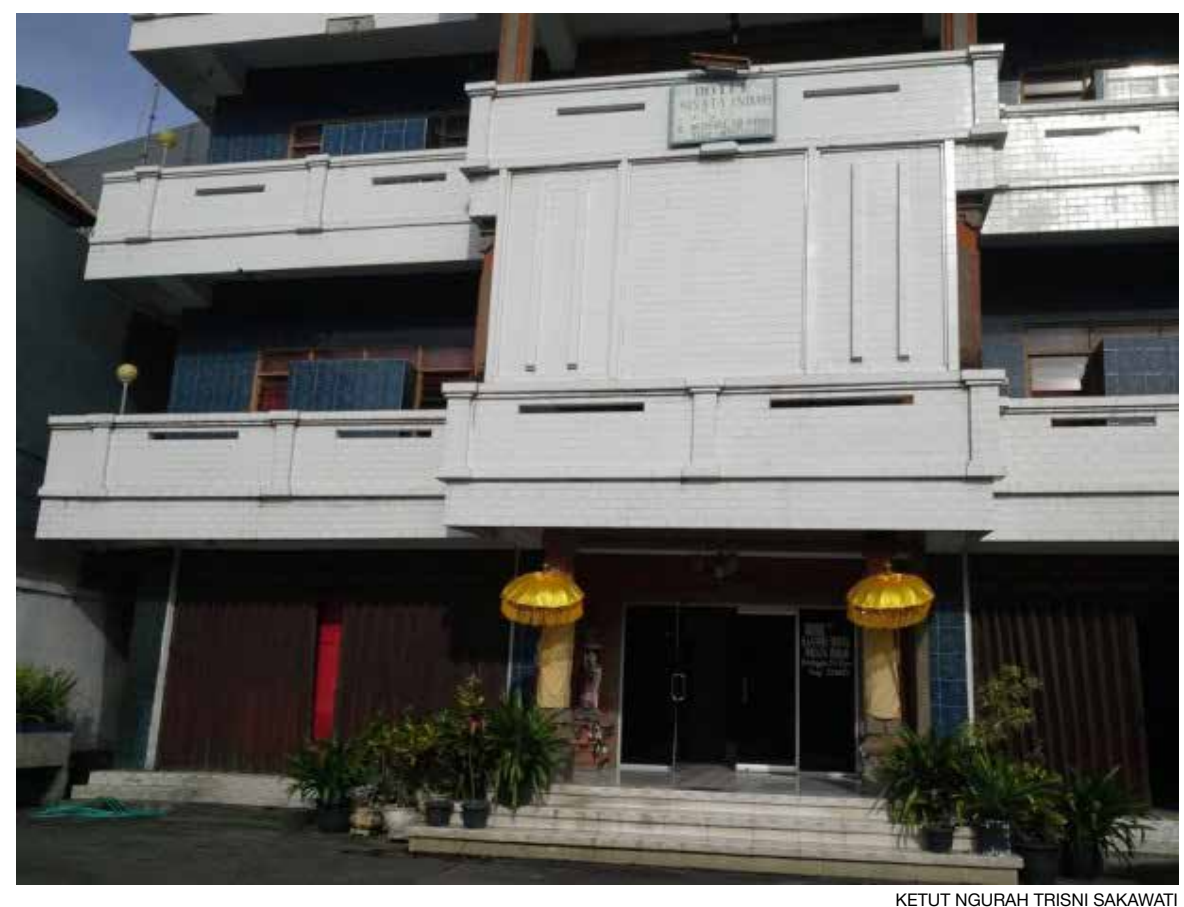

Foto 3. Sebuah hotel kelas melati di Denpasar.

merasakan dampak negatif dari menjamurnya hotel-hotel baru yang disebut sebagai city hotel di Kota Denpasar. Dampak yang dirasakan adalah adanya persaingan tarif kamar (room rate), karena dengan adanya keberadaan beberapa city hotel tersebut, hotel kelas melati tidak bisa menaikkan tarif kamar padahal biaya operasional terus meningkat. Pengelola hotel menyatakan tidak berani menaikkan harga sewa kamar karena khawatir para pelanggannya berpindah ke hotel lain di sekitarnya

Gambaran terjadinya persaingan harga sewa kamar menjelaskan bahwa perkembangan city hotel di Kota Denpasar telah memberikan dampak negatif terhadap usaha hotel melati karena tidak dapat meningkatkan harga sewa kamar secara tidak langsung juga memengaruhi pendapatan hotel.

Sedangkan untuk faktor jumlah tamu yang menginap juga berhubungan secara langsung dengan tingkat hunian hotel yang secara jelas digambarkan bahwa hotel-hotel kelas melati hanya akan tinggi tingkat hunian hotelnya pada saat liburan sekolah, hari raya Lebaran ataupun di akhir tahun. Pada hari-hari biasa tamu bisnis lebih memilih city hotel yang lokasinya strategis dengan harga yang tidak jauh beda dengan sewa kamar hotel melati.

Dalam situasi persaingan ketat dengan city hotel menyebabkan pendapatan hotel melati di Kota Denpasar mengalami penurunan. Penurunan pendapatan hotel disebabkan menurunnya tingkat hotel dan lama tinggal tamu di hotel melati. Terjadinya penurunan tingkat hunian hotel karena tamu yang datang 
hanya pada waktu tertentu. Dengan demikian pada waktu selain liburan, tingkat hunian hotel melati sangat rendah.

Dari penjelasan di atas, dari faktor persaingan harga sewa kamar, menurunnya tingkat hunian hotel, berkurangnya pendapatan hotel dan terpaku pada jenis tamu tertentu pada hotel melati, telah menggambarkan dampak negatif yang diakibatkan oleh pesatnya perkembangan city hotel di Kota Denpasar.

Selain faktor tersebut, juga disebutkan beberapa dampak negatif yang timbul seperti terjadinya kemacetan pada ruas jalan pada saat masa liburan tiba. Hal ini disebabkan bila hotel tidak memiliki luas lahan yang memadai untuk menampung bis-bis yang mengangkut tamu hotel.

Dampak negatif yang terjadi akibat tingginya perkembangan city hotel, tidak saja memengaruhi usaha hotel melati, namun juga kepada masyarakat luas. Adapun dampak negatif yang ditimbulkan seperti terjadinya kriminalitas saat pembangunan fisik ataupun dapat meningkatkan peredaran narkoba di hotel-hotel. Secara bisnis, kondisi murahnya harga sewa kamar akan sangat menguntungkan para pengusaha Biro Perjalanan Wisata, karena dapat menjual paket tur yang semurah-murahnya. Rendahnya harga paket tur yang ditawarkan dapat menjadikan Bali sebagai destinasi murahan.

Mencermati dari hasil penelitian di atas maka perkembangan city hotel di Kota Denpasar memang sangat mengkhawatirkan pengusaha hotel melati, bukan saja karena adanya persaingan harga sewa kamar yang tidak sehat ataupun menurunnya tingkat hunian hotel tetapi adanya Peraturan Walikota Denpasar Nomor 24 Tahun 2013 tentang Tanda Daftar Usaha Pariwisata yang mensyaratkan agar pengusaha jenis usaha penyediaan akomodasi hotel wajib berbentuk badan usaha Indonesia berbadan hukum. Hal ini menimbulkan permasalahan diantara para pengusaha hotel melati yang sebagian besar dikelola oleh keluarga/ perseorangan karena kondisi ini dikhawatirkan akan mengancam keberlangsungan pengusaha hotel lokal itu sendiri, sebagaimana yang disampaikan oleh A.A. Ngurah Adhi Ardana,ST, Pengurus PHRI Kota Denpasar (Wawancara, 4 Februari 2015).

Dampak negatif tersebut tidak dapat dibiarkan begitu saja dan harus dicarikan solusi agar usaha hotel melati dapat ikut bersaing dalam bisnis usaha sarana akomodasi dan tetap bertahan dengan mempertahankan budaya lokal namun tetap profesional dalam melayani tamu. Untuk mengantisipasi dampak negatif yang terjadi akibat perkembangan city hotel di Kota Denpasar pengelola hotel berupaya melakukan beberapa hal sebagai dalam ulasan di bawah ini.

Perkembangan city hotel di Kota memberikan beberapa dampak positif antara lain, seperti yang disampaikan oleh Pengelola Hotel Puri Nusa Indah, A.A. Ngr. Alit.Virman, dengan adanya city hotel, pengusaha hotel melati dituntut untuk meningkatkan kualitas pelayanan dan sumber daya 
manusianya terutama dalam teknologi terkini seperti penguasaan sistem booking online dan kemampuan berbahasa. Peningkatan kualitas SDM dan perangkat elektronik tentu bukan barang murah, namun merupakan investasi biaya tinggi yang diharapkan dapat bermanfaat untuk menghadapi Masyarakat Ekonomi ASEAN 2015 ini (Wawancara, 5 Februari 2015).

Dampak positif lainnya juga disampaikan oleh Pengelola Hotel Puri Gatsu Indah, persaingan antar-hotel memang tidak dapat dihindari, namun untuk bertahan di bisnis perhotelan adalah dengan tetap menjaga kebersihan kamar, meningkatkan pelayanan dan fasilitas hotel. Untuk itu, pengelola hotel selalu menekankan kebersihan kepada para pelayan hotel agar membersihkan kamar dan lingkungan pada saat hotel sedang sepi.

Banyaknya city hotel membuat para pengusaha hotel melati semakin gencar mempromosikan hotelnya, seperti diungkapkan oleh A.A.Ngr. Gede Setyawan, ST, Pengelola Hotel Ratu. Promosi dilakukan dengan berbagai cara seperti penyebaran brosur, bekerja sama dengan online ataupun offline travel agent, bekerjasama dengan pramuwisata, sopir taxi, memberikan harga khusus untuk para tamu ataupun berpromosi melalui media sosial facebook. Untuk menarik para tamunya, hotel ini juga sudah merenovasi beberapa kamar dan lingkungannya untuk meningkatkan fasilitas kamar sehingga harga sewa kamar dapat dinaikkan (Wawancara, 19 Januari 2015).

Selain dampak positif terhadap pengusaha hotel melati, perkembangan city hotel di Kota Denpasar juga memberi manfaat bagi masyarakat umum dan tamu. Dengan adanya city hotel, juga dapat memberikan peluang kerja untuk menyerap tenaga kerja lokal dan meningkatkan perekonomian masyarakat sekitar seperti yang disampaikan oleh Pengurus ASITA Bali, Ketut Ardana, SH demikian pula yang disampaikan oleh Camat Denpasar Barat, Sekretaris Camat Denpasar Utara, Drs. Raka Purwantara, MAP (Wawancara, 27 Januari 2015). Pengelola city hotel juga secara rutin memberikan bantuan dana pada saat ada kegiatan adat di sekitarnya melalui Pengurus Banjar.

Dampak yang paling nyata dengan adanya city hotel adalah memberikan nilai tambah terhadap fasilitas sarana akomodasi di Kota Denpasar dan apabila pembangunan city hotel ditata dengan baik sesuai dengan peruntukan dan menyebar bukan berada di satu wilayah, bisa jadi pembangunan city hotel justru menampilkan wajah Kota Denpasar yang lebih tertata.

Suatu daerah yang melakukan pembangunan pasti mengalami perkembangan. Perkembangan yang terjadi akan memberikan dampak bagi masyarakat baik dampak postif ataupun negatif. Demikian pula dengan perkembangan city hotel di Kota Denpasar telah memberikan dampak positif dan negatif terhadap usaha hotel melati seperti pembahasan di atas.

Adanya dampak negatif dan positif pada perkembangan city hotel di Kota Denpasar memang tidak dapat dihindari, sebagaimana diketahui bisnis pariwisata, khususnya bisnis perhotel sangatlah dinamis. Untuk 
menghindari persaingan yang tidak sehat dan demi keberlangsungan pariwisata Bali selanjutnya, Pemerintah perlu menetapkan beberapa kebijakan kepariwisataan. Kebijakan kepariwisataan khususnya di bidang sarana akomodasi yang lebih spesifik karena sifat bisnis ini merupakan bisnis jasa yang mengutamakan pelayanan dan kepuasan pelanggan.

Hasil penelitian menunjukkan informasi dari para informan menyampaikan beberapa dampak negatif yang terjadi akibat perkembangan city hotel yaitu terjadinya persaingan yang tidak sehat antar hotel. Untuk mengantisipasi persaingan harga sewa kamar antar hotel yang semakin tidak sehat, Pemerintah Kota Denpasar diharapkan menyusun suatu kebijakan yang mengatur standar harga sewa kamar hotel sesuai dengan fasilitas yang ditawarkan dan tidak mengobral harga sehingga harga sewa kamar hotel melati berada di titik terendah.

Pemerintah Kota Denpasar diharapkan agar lebih selektif memberikan izin usaha hotel, mengatur pembangunan hotel dengan membatasi pembangunan di wilayah yang sudah padat dan melaksanakan moratorium dengan tegas. Pemerintah Kota Denpasar disarankan untuk membuat kajian mengenai city hotel yang berjaringan internasional agar keberadaannya tidak menjadi momok bagi hotel kelas melati serta menyusun kajian tentang kebutuhan kamar hotel yang diperlukan di Kota Denpasar agar jumlah tamu menginap sesuai dengan jumlah kamar yang tersedia sehingga hotel mendapatkan bagian secara merata.

Dengan telah terimplementasinya kebijakan kepariwisataan dalam suatu produk hukum diharapkan dapat menjadi pedoman dalam menjaga iklim usaha sarana akomodasi di Kota Denpasar tetap kondusif dapat menarik kunjungan wisatawan lebih banyak lagi, meningkatkan jumlah tamu menginap dan tingkat hunian hotel sehingga meningkatkan pendapatan hotel sehingga kepariwisataan di Kota Denpasar dapat meningkatkan kesejahteraan masyarakat.

\section{Persaingan dan Strategi Bisnis City Hotel serta Pengaruhnya terhadap Strategi Bisnis Hotel Melati}

Perkembangan city hotel di Kota Denpasar tidak saja memberikan dampak kepada usaha hotel melati untuk bertahan, juga menimbulkan dampak yaitu sebuah persaingan antar-city hotel. Untuk mengetahui persaingan yang dirasakan oleh pengelola hotel akibat pesatnya perkembangan city hotel di Kota Denpasar dan strategi yang dilakukan untuk menghadapi persaingan yang ada, peneliti melakukan wawancara dengan pengelola city hotel dan hotel melati.

Berkembangnya city hotel terutama yang dikelola oleh hotel manajemen berjaringan internasional menyebabkan jenis tamu yang diterima oleh hotel melati hanya tamu rombongan yang datang hanya pada saat liburan, 
sedangkan tamu bisnis ataupun tamu perseorangan lebih banyak memilih city hotel.

Menurunnya tingkat hunian dan pendapatan hotel juga melanda city hotel karena persaingan ketat antar-city hotel yang lokasinya saling berdekatan. Selain adanya persaingan harga sewa kamar antar-cityhotel, perpindahan karyawan (employee turnover) antar hotel juga sering terjadi. Terbukanya kesempatan kerja di dunia perhotelan juga memudahkan tenaga kerja yang memiliki pengalaman dan ketrampilan yang cukup untuk berpindah dari satu hotel ke hotel lainnya dan mencari hotel yang memberikan penghasilan yang tinggi. Mencermati hal tersebut, pemilik dan manajemen hotel harus mampu mengelola sumber daya manusia yang dimiliki dengan baik untuk mencegah tingginya perpindahan karyawan agar tidak memengaruhi pelayanan kepada tamu.

Tingginya tingkat persaingan bisnis city hotel di Kota Denpasar telah menimbulkan berbagai dampak oleh karena itu pengelola city hotel melakukan berbagai upaya untuk dapat bertahan. Upaya yang dilakukan antara lain dengan menyiapkan beberapa strategi seperti strategi harga, pasar dan pemasaran hotelnya. Strategi bisnis adalah bagaimana merebut pasaran di tengah masyarakat. Bagaimana menempatkan organisasi di hati para penguasa, para pengusaha, para donor dan sebagainya. Semua itu dimaksudkan untuk dapat memperoleh keuntungan-keuntungan stratejik yang sekaligus mampu menunjang berkembangnya organisasi ke tingkat yang lebih baik. ${ }^{2}$

Hubungan antara penyusunan strategi dengan teori penawaran dan permintaan adalah pengelola hotel mencoba menetapkan strategi harga dan promosi untuk memenuhi permintaan tamu dalam mengantispasi persaingan city hotel di Kota Denpasar. Pengelola city hotel melakukan strategi dengan memberikan harga lebih rendah dari harga resmi demi dapat bersaing dengan hotel lain. Fenomena ini tidak sesuai dengan teori penawaran pada umumnya, yang menggambarkan situasi dimana semakin tinggi harga suatu barang, makin banyak jumlah barang yang ditawarkan oleh para penjual, sebaliknya makin rendah harga suatu barang, makin sedikit jumlah barang yang ditawarkan. Namun, dalam kenyataannya, pengelola hotel justru menawarkan harga sewa kamar serendah-rendahnya sesuai dengan perhitungan perusahaan demi dapat bersaing dengan hotel lainnya.

Strategi lainnya adalah dengan melakukan berbagai upaya promosi dengan berbagai pihak seperti mengikuti kegiatan pemasaran secara langsung (table top, ataupun sales call), bekerja sama dengan Online dan Offline Travel Agent. Untuk dapat bertahan di bisnis perhotelan di Kota Denpasar saat ini sangat sulit mengingat semakin hari jumlah hotel semakin meningkat sehingga para

2 http://manajemena2011.blogspot.com/2013/04/pengertian-manajemen-strategi.html\#sthash. aFg2d1EV.dpuf (diakses pada tanggal 2 Mei 2015) 
pengelola menyusun paket-paket yang dapat ditawarkan kepada para tamu seperti paket meeting. Selain itu juga dilakukan penawaran terhadap fasilitas hotel untuk kegiatan rapat, pernikahan, wisuda ataupun menyusun paket untuk kegiatan tertentu seperti yang dilakukan Pengelola Hotel Inna Bali.

Strategi lainnya adalah menjaga segmen yang telah ada. Untuk itu pengelola hotel berusaha menjalin hubungan dengan pelanggannya melalui media sosial, e-mail ataupun berita singkat (Short Message Service) untuk menginformasikan program ataupun penawaran hotel yang paling terkini.

Perkembangan city hotel di Kota Denpasar telah meningkatkan persaingan antar-city hotel sehingga pengelola hotel menyusun berbagai strategi agar dapat tetap bertahan. Kondisi tersebut memaksa sejumlah pengelola hotel melati menyusun strategi bisnisnya agar tidak semakin terpuruk. Dari hasil wawancara dengan 13 pengelola hotel melati, pada dasarnya strategi bisnis yang ditetapkan tidak berbeda dengan city hotel yaitu strategi harga, promosi dan menjaga segmen yang telah menjadi pelanggannya.

Salah satu strategi harga yang dilakukan oleh pengelola Hotel The Grand Santhi adalah memberikan potongan harga sewa kamar hingga 50\% pada saat low season.. Untuk menutupi biaya operasional pada musim sepi, pengelola Hotel Warta Sari menaikkan harga sewa kamarnya hampir dua kali lipat saat high season atau peak season. Berbeda dengan Hotel The Bali Rama City yang menawarkan harga sewa kamarnya dengan harga terendah sekitar Rp. 288.0oo hanya untuk tiga kamar saja sebagai penarik perhatian tamu.

Promosi mempunyai peranan penting dalam melakukan penjualan. Promosi akan efektif jika sasaran dan komunikasi yang dilakukan tepat sasaran. Demikian pula halnya yang dilakukan oleh pengelola Hotel Cianjur memilih berpromosi dengan beriklan di Buku Yellow Pages yang peredarannya di luar Bali, menyebarkan brosur kepada travel agent dan melalui website hotel. Berpromosi di buku Yellow pages juga dilakukan oleh pengelola Hotel Puri Nusa Indah, Hotel Wisata Indah, Hotel Mutiara dan Hotel Warta Sari. Hotel-hotel lainnya, seperti Hotel Puri Royan dan Hotel Puri Gatsu Indah mempromosikan hotelnya dengan melakukan kerjasama dengan sopir taksi dan pramuwisata.

Strategi lainnya adalah menjaga segmen atau pasar yang telah dimiliki dengan menyediakan fasilitas dan pelayanan yang diiinginkan oleh tamu. Mencermati dari ulasan di atas, dapat disimpulkan bahwa perkembangan city hotel di Kota Denpasar telah berdampak kepada usaha hotel melati dan juga antar-city hotel.

\section{Simpulan dan Saran}

Berdasarkan hasil analisis dan pembahasan yang telah dilakukan dalam penelitian ini, maka dapat diperoleh simpulan sebagai berikut :

Pertama, dampak menjamurnya city hotel membuat kurang lakunya hotel 
melati di Kota Denpasar. Kondisi ini yang membuat semakin melemahnya usaha hotel melati di Kota Denpasar, karena tamu lebih memilih city hotel yang fasilitasnya lebih bagus daripada hotel melati. Dari hasil penelitian dengan faktor internal dan eksternal yang paling menarik perhatian adalah persaingan harga sewa kamar. Dari faktor harga sewa kamar ini ditemukan bahwa fenomena saat ini hukum penawaran tidak sesuai dalam bisnis hotel di Kota Denpasar. Dari sisi hukum permintaan, semakin murah harga sewa kamar hotel semakin meningkatkan minat tamu untuk memilih hotel tersebut.

Kedua, ditemukan ada dua dampak perkembangan city hotel terhadap usaha hotel melati di Kota Denpasar yaitu dampak negatif dan positif. Dampak negatif dari perkembangan city hotel terhadap usaha hotel melati antara lain: terjadinya persaingan harga sewa kamar, menurunnya tingkat hunian serta pendapatan hotel melati. Dampak negatif lainnya akibat perkembangan city hotel adalah terjadinya kemacetan pada ruas jalan dan kemungkinan terjadinya kriminalitas. Selain adanya dampak negatif muncul pula upaya yang dilakukan oleh pengusaha hotel melati untuk mengantisipasi perkembangan city hotel dengan meningkatkan pelayanan dan fasilitas hotelnya, menggencarkan promosi serta menjaga hubungan dengan pelanggannya. Manfaatnya bagi masyarakat adanya peluang kerja dan dapat meningkatkan perekonomian masyarakat.

Ketiga, perkembangan city hotel di Kota Denpasar tidak saja mempengaruhi usaha hotel melati namun telah menyebabkan terjadinya persaingan dan antar-city hotel itu sendiri. Dalam mengantisipasi persaingan, pengelola city hotel dan hotel melati telah melakukan strategi untuk tetap bertahan. Adapun strategi yang dilakukan adalah strategi harga, promosi dan menjaga segmen yang telah dimiliki dengan memberikan pelayanan yang diinginkan tamu.

Berdasarkan hasil analisis dan pembahasan yang telah dilakukan dalam penelitian ini, maka dapat diberikan beberapa saran untuk mengatasi pesatnya perkembangan city hotel di Kota Denpasar dengan rincian sebagai berikut.

Pertama, perlunya menyusun sebuah kajian tentang kebutuhan kamar hotel yang dibutuhkan di Kota. Adanya beberapa kebijakan mengenai sarana akomodasi antara lain: Kebijakan yang mengatur standar harga sewa kamar hotel minimum dan maksimal sesuai dengan fasilitas yang disediakan sehingga tidak terjadi persaingan harga, Kebijakan tentang pemerataan pembangunan hotel di wilayah Kota Denpasar sesuai dengan peruntukan yang ditetapkan dalam RTRW Kota Denpasar, Kebijakan tentang pencegahan alih fungsi lahan dengan merancang secara detail peruntukan wilayah khusus pembangunan sarana akomodasi, Kebijakan mengenai peningkatan kualitas daya tarik wisata di Kota Denpasar. 
Kedua, pentingnya mensosialisasikan Peraturan Walikota Denpasar Nomor 24 Tahun 2013 tentang Tanda Daftar Usaha Pariwisata kepada pengusaha hotel lokal untuk memberikan pengertian bahwa peraturan tersebut disusun demi memberikan kepastian hukum dalam menjalankan usaha pariwisata di Kota Denpasar.

Ketiga, menyarankan kepada pengelola hotel melati terus meningkatkan kualitas fasilitas dan pelayanan hotel serta meningkatkan kualitas sumber daya manusia terutama di bidang bahasa dan teknologi agar dapat bersaing dalam menghadapi masuknya tenaga kerja dari luar dengan mulai berlakunya Masyarakat Ekonomi ASEAN pada akhir 2015.

\section{Ucapan Terima Kasih}

Penulis mengucapkan terima kasih yang tulus kepada Prof. Dr. I Nyoman Darma Putra, M.Litt. selaku Pembimbing I, juga selaku Ketua Program Studi Magister Kajian Pariwisata Universitas Udayana dan Dr. Dewa Putu Oka Prasiasa, A.Par, MM. selaku Pembimbing II yang dengan penuh perhatian dan kesabaran telah memberikan dorongan, semangat, bimbingan, serta saran selama penulisan artikel ini. Ucapan terima kasih kepada para dosen penguji Prof. Dr. I Wayan Ardika, M.A, Prof. Dr. Ir. Made Antara, MS dan Dr. Ida Bagus Ketut Surya, SE., M.Si. serta Dr. Ir. Syamsul Alam Paturusi, MSP sebagai Sekretaris Program Studi Magister Kajian Pariwisata Universitas Udayana yang telah memberikan masukan, saran dan koreksi untuk menyempurnakan artikel ini. Ucapan terima kasih kepada Para Dosen, Staf Sekretariat Program Studi Magister Kajian Pariwisata Universitas Udayana serta teman-teman atas dukungan dan kerjasamanya selama masa perkuliahan dan penulisan artikel.

\section{Daftar Pustaka}

Badan Pusat Statistik (BPS) Bali. 2012. Bali Dalam Angka.

Badan Pusat Statistik (BPS) Denpasar. 2014. Statistik Hotel Kota Denpasar 2013.

Badan Pusat Statistik (BPS) Denpasar. 2014. Denpasar Dalam Angka.

Badan Pusat Statistik (BPS) Denpasar. 2014. Statistik Daerah Kota Denpasar 2014.

Bagian Humas dan Protokol Setda. Kota Denpasar. 2014. Data Mini Selayang Pandang Kota Denpasar.

Badan Perencanaan Pembangunan Kota Denpasar (BAPPEDA). 2014. Rencana Kerja Pembangunan Daerah Kota Denpasar 2015.

Bagyono. 2012. Pariwisata dan Perhotelan. Bandung: CV. Alfabeta.

Budi, Agung Permana. 2013. Manajemen Marketing Perhotelan. Yogyakarta: CV. Andi Offset.

Darminto, Dwi Prastowo dan Suryo, Aji. 2005. Analisis Laporan Keuangan Hotel. Yogyakarta: CV. Andi Offset.

Dinas Pariwisata Provinsi Bali. 2014. Direktori Berïin Usaha di Provinsi Bali 2013. 
Dinas Pariwisata Kota Denpasar. 2013. Direktori Pariwisata Denpasar 2013.

Dinas Pariwisata Kota Denpasar. 2013. Data Pariwisata Kota Denpasar 2013.

Dinas Pariwisata Kota Denpasar. 2014. Profil Dinas Pariwisata Kota Denpasar 2014.

Dinas Pariwisata Provinsi Bali. 2014. Data Kepariwisataan di Bali Tahun 2013.

Gunawan, Imam. 2013. Metode Penelitian Kualitatif: Teori dan Praktik. Jakarta: PT Bumi Aksara.

Ismayanti, 2010. Pengantar Pariwisata. Jakarta: PT Gramedia Widiasarana Indonesia.

Kreag, Glenn. 2001. The Impacts of Tourism. Minnesota: Sea Grant.

Kotler, Philip dan Amstrong, Gary. 2001. Prinsip-prinsip Pemasaran. Jakarta: Erlangga.

Marlina, Endy. 2008. Panduan Perancangan Bangunan Komersial. Yogyakarta: CV. Andi Offset.

Mason, Peter. 2003. Tourism Impacts, Planning and Management. Burlington: Butterworth-Heinemann.

Payne, Adrian. 2000. The Essence of Service Marketing (Pemasaran Jasa). Yogyakarta: CV Andi Offset.

Pitana, I Gede dan Gayatri, Putu G. 2005. Sosiologi Pariwisata. Yogyakarta: CV Andi Offset.

Pitana, I Gede dan Diarta, Surya. 2009. Pengantar Ilmu Pariwisata. Yogyakarta: CV Andi Offset.

Singarimbun, Masri dan Efendi, Sofian. 1995. Metode Penelitian Survei. Jakarta: PT Pustaka LP3ES Indonesia.

Soewirjo, Herdi S. Darmo. 2003. Teori dan Praktik Akutansi Perhotelan. Yogyakarta: CV Andi Offset.

Sunaryo, Bambang. 2013. Kebijakan Pembangunan Destinasi Pariwisata (Konsep dan Aplikasinya di Indonesia). Yogyakarta: Gava Media.

Sugiyono. 2010. Metode Penelitian Kuantitatif, Kualitatif dan R\&D. Bandung: CV Alpabeta.

Sukirno, Sadono. 1985. Pengantar Teori Mikroekonomi. Jakarta: Lembaga Penerbit Fakultas Ekonomi UI dengan Bima Grafika.

Wahab, Solichin Abdul. 2014. Analisis Kebijakan: Dari Formulasi ke Penyusunan Model-Model Implementasi Kebijakan Publik. Jakarta: PT Bumi Aksara.

Wardiyanta. 2006. Metode Penelitian Pariwisata. Yogyakarta: CV. Andi Offset.

Yoeti, Oka. A. 2005. Perencanaan Strategis Pemasaran Daerah Tujuan Wisata. Jakarta: PT. Pradnya Paramita.

\section{Peraturan dan Perundang-undangan}

Keputusan Menteri Kebudayaan dan Pariwisata, Nomor: KM.3/HK.001/MKP.o2, tentang Penggolongan Kelas Hotel.

Peraturan Daerah Kota Denpasar, Nomor: 24 Tahun 2001, tentang Usaha Hotel Melati.

Peraturan Daerah Kota Denpasar, Nomor: 27 Tahun 2011, tentang Rencana Tata 
Ruang Wilayah Kota Denpasar Tahun 2011-2031.

Peraturan Menteri Kebudayaan dan Pariwisata Republik Indonesia, Nomor: PM 86/HK. 501/ MKP/ 2010, tentang Tata Cara Pendaftaran Usaha Penyediaan Akomodasi.

Peraturan Menteri Kebudayaan Pariwisata Republik Indonesia, Nomor: PM 87/ HK.501/ MKP/ 2010 tentang Tata Cara Pendaftaran Usaha Jasa Makanan dan Minuman,

Peraturan Menteri Kebudayaan dan Pariwisata Nomor: PM 91/ HK.501/ MKP/ 2010 tentang Tata Cara Pendaftaran Usaha Penyelenggaraan Kegiatan Hiburan dan Rekreasi.

Peraturan Menteri Pariwisata dan Ekonomi Kreatif Republik Indonesia, Nomor: PM 53/HK. 001/ MPEK/ 2013, tentang Standar Usaha Hotel.

Peraturan Wali Kota Denpasar, Nomor: 31 Tahun 2007, tentang Usaha Hotel Bintang. Peraturan Wali Kota Denpasar, Nomor: 24 Tahun 2013, tentang Tanda Daftar Usaha Pariwisata.

Peraturan Wali Kota Denpasar, Nomor: 26 Tahun 2014, tentang Petunjuk Pelaksanaan Usaha Akomodasi, Jasa Makanan dan Minuman, Kegiatan Hiburan dan Rekreasi.

Undang-Undang Republik Indonesia, Nomor: 9 Tahun 1990, tentang Kepariwisataan. Undang-Undang Republik Indonesia, Nomor 10 Tahun 2009, tentang Kepariwisataan. Sumber Internet

http://tentangpariwisata. blogspot.com/2010/12/apa-itu-kebijakan kepariwisataan. html

Kajian Normatif Pembentukan Peraturan Perundangan sebagai Instrumen Kebijakan Pemerintah, https://interspinas.wordpress.com/2010/01/27/13/.

http://tipsserbaserbi.blogspot.com/2014/12/pengertian-bisnis-menurut-para-ahli. html (diakses pada tanggal 30 April 2015)

http://www.apapengertianahli.com/2014/12/pengertian-strategi-menurut beberapa-ahli.html\# (diakses pada tanggal 2 Mei 2015)

http://manajemena2011.blogspot.com/2013/o4/pengertian-manajemen-strategi. html\#sthash.aFg2d1EV.dpuf (diakses pada tanggal 2 Mei 2015)

\section{Profil Penulis}

Ketut Ngurah Trisni Sakawati adalah seorang PNS pada Badan Penanaman Modal dan Perizinan Provinsi Bali. Ia menyelesaikan S1 pada tahun 1989 pada Jurusan Sastra Inggris, Fakultas Sastra, Universitas Udayana dan melanjutkan Program Studi Magister Kajian Pariwisata, Universitas Udayana tahun 2013 atas biaya Pemerintah Provinsi Bali. 